\title{
An Overview on Analysis and Control of Micro-grid System
}

\author{
Jingwei Hu, Tieyan Zhang, Shipeng Du and Yan Zhao \\ Shenyang Institute of Engineering, Shenyang, China \\ hjw_sie@163.com
}

\begin{abstract}
Micro-grid control is the key technology in the process of accessing micro-grid into regular grid. This paper summarizes several ways on coordination control in micro-grid and introduces some domestic researches on micro-grid control strategies. It is written on the basis of the achievements on micro-grid control in some developed countries and current situations on domestic micro-grid control. Firstly, the paper introduces the objects of micro-grid control study and describes the control processes of each object thoroughly on different micro-grid control structures. Then the paper states the researches among the world on micro-grid control generally. In the end, the paper discusses the research orientation on micro-grid control which based on the existing problems of micro-grid control and current situations on regular grid.
\end{abstract}

Keywords: micro-grid, coordination control, mode switch, energy management system

\section{Introduction}

With the development of power electronic and energy storage technology, micro-grid technology grows great popularity in electric power system. Micro-grid is a distribution subsystem combined by distribution generators (DG), inverters, energy storage system, loads and monitor devices. Micro-grid mainly has two operational modes: the gridconnected mode and the islanding mode. Grid-connected mode means assisting and saving the fossil energy when the regular micro-grid operates well. While islanding mode means supplying electricity only for significant loads and making the loads operate continuously when the regular grid breaks down. Therefore, to realize the micro-grid switching into the two operational modes automatically and to make sure the whole net has no or little fluctuation, micro-grid control has always been deemed as the key and core technology in the process of accessing micro-grids into regular grids. To take the micro-grid whose DG is photovoltaic arrayed as an example, Figure 1 is the micro-grid basic system structure provided by CERTS.

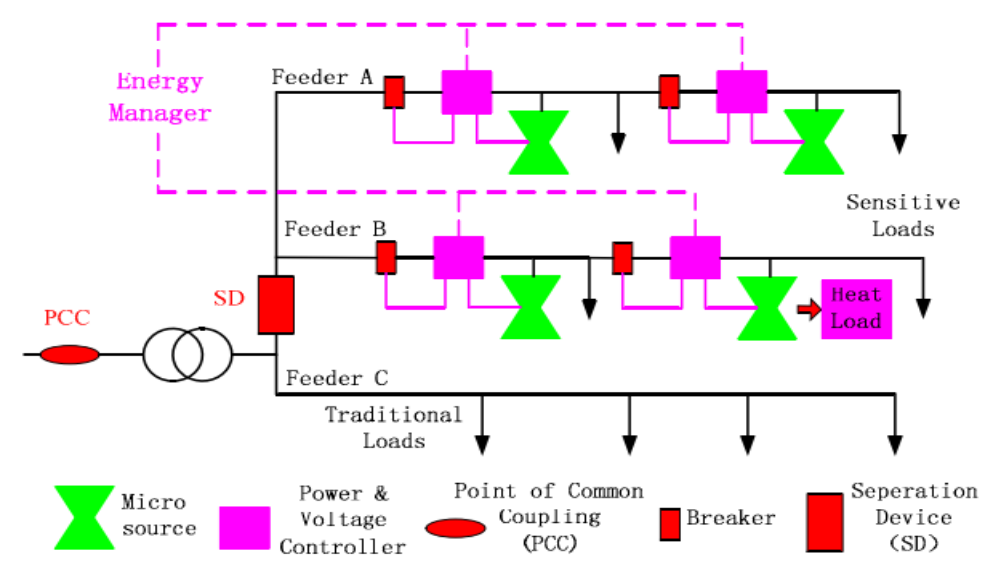

Figure 1. Basic Structure of Micro-Grid [1] 
Micro-grid CERTS proposed is constituted mainly based on power electronic technology, load and small power whose capacity is less than $500 \mathrm{~kW}$. The structure reflects the basic characteristics of the micro-grid preliminarily, and also reveals the key unit of micro-grid:

(1) Each interface, control of micro-power;

(2) The energy manager of the total micro-grid solves the voltage control, tide control and load distribution, stability, and all running problems when micro-grids are disconnected;

(3) It has the protection of the relay, including the various micro-powers and the protection of the whole micro-power grid control [2].

As shown in the figure, CERTS micro-grid covers 3 feeders, A, B, C and load. The whole network seems like a radial structure. In the micro-grid system, the micro-power can be photovoltaic power generation, micro gas turbines, fuel cells, and all other forms. When the micro-power is put near the heat users, it can provide heat source for local users, and make full use of the energy.

\section{Objects in Micro-Grid Control}

As is shown in Figure 1, the energy management system (EMS) is composed of photovoltaic arrays and accumulators. The inverter can switch between the gridconnected and islanding modes, and the load management system can be built on load classification and power supply priority. Set the PCC point on the bus which is parallel to the regular grid and monitors the output voltage, frequency and power of the micro-grid.

\subsection{Energy Management System}

Compared with regular grid, the micro-grid has characteristics of randomness and intermittency. When the micro-grid massively accesses into the regular grid, as beneficial additions for micro-grid generating, energy storage technology controlled by EMS can smooth the output power of both randomness and intermittency. According to micro-grid system structure, EMS can control the smooth delivery for output power, when the grid-connected and islanding conditions switch into each other. In the reference [3], the combination of cascade control and local control is proposed as a method to compensate power fluctuations caused by loads and renewable energy sources in a micro-grid with distributed power generation systems-(DGs). Reference [4] presents the hierarchical control methods based on multi-agent system, which are also presented for micro-grid system energy compatibility. It presents structures made by JADE flat of element layers, single micro-grid layers, multi-microgrid layers and distribution network layers. It also presents energy compatibility process and optimization goals for multi-micro-grid system with the structures of self-control and coordination, and achieves energy coordination within the micro-grid under the steady-state operation. Reference [5] develops a small-signal dynamic model for a multiple-DG micro-grid system to investigate the dynamic behavior of a micro-grid under the proposed PMSs. In reference [6] an aggregated controller for autonomous micro-grids (MGs) supplied by wind and hydro renewable energy has been proposed. Reference [7] sets a typical micro-grid including photovoltaics, wind farm, energy storage and energy management system, and introduces the configuration of micro-grids based on energy storage and its control. 


\subsection{Grid-connected Inverter based on MPPT Control}

Inverters play an important part in distribution grid connection and distribution generators. Controlled by maximum power point tracking (MPPT), the inverter can release the energy control by monitoring the PCC power points. If the power which micro-grid supplied is less than the loads' power consumption, the power produced by micro-grids will only be provided for only a part of loads to meet their needs. On contrary, the surplus produced by micro-grids will charge for the energy storage devices. Reference [8] provides the best controlling strategies for micro-grid connection:

(1) When the grid connects, the voltage difference on both sides of the switch must be a small value, 0 in a perfect condition;

(2) Grid frequency must be a little higher than micro-grid frequency;

(3) When the grid connects, the grid's voltage must be ahead of micro-grid's voltage.

Reference [9] puts forward an active and synchronous control strategy based on the principle of phase-locked loop. This new strategy shows that by actively controlling the buses' voltage frequencies, phase angles and amplitudes, one can monitor the main electric grid's voltage and reduce the voltage deviation at the grid connected moment. Thus, the smooth transition from the islanding mode to grid connected mode can be achieved. Reference [10] puts forward the smooth switching control strategy in section 3 referring to the match level of micro-power capacity and loads inside the micro-grid. The strategy can effectively reduce the transient oscillations in switching within the two modes. Reference [11] designs a voltage type inverter adjusted by sine current pulse-width modulation (PWM), according to distribution generation's external characteristic of loads. Thus the external characteristic of inverter-based distribution generation (IBDG) constant power voltage source can be maintained in a better way and the harmonic wave can be infused better also.

\subsection{PCC Point Power Quality}

The grid's voltage, frequency, phase angle and other parameters are uploaded through the grid monitoring devices. When a micro-grid connects with distribution network, voltage and frequency of normal grid need to be compared with the microgrid and analyze whether they are synchronized. If the deviation exceeds the permissible limits, the energy storage device and the photovoltaic battery's power output shall be adjusted. Meanwhile, EMS will calculate the compensation for reactive power, send the value to the energy storage device, and keep the whole system in balance by ordering the storage device to send the reactive power.

If some power failure or power quality problems that may interrupt the voltage in distribution network are monitored by the monitoring system, PCC point controller will send some signal to breakers, which will be disconnected and the micro-grid will turn into islanding mode. When the distribution network has resumed operations, the monitoring equipment's will detect the voltage, frequency and phase angle for both the current power grids and micro-grids. If the values for both are not synchronous, EMS will adjust the power output and make them synchronized as soon as possible.

\subsection{The Load Controller}

At PPC point, besides putting the power quality parameters monitoring device, it can also place a controller based on the load priority. When the distributed power generation is higher than the load power consumption, the micro-grid will supply power to load directly. When the capacity does not meet the demands of all load 
power, load controller will send orders to load switch based on the load priority to preset to disconnect with the secondary load, only supply power to important loads. At the same time, DGs supply the surplus power to the energy storage equipment.

\section{The Strategy of Micro-Grid Control}

In micro-grid system, due to various micro-power types, it is difficult to control them in coordinating to establish a stable voltage and frequency. Now the control strategy commonly used is divided into master-slave station control, the droop control and control based on multi-agent technology, etc., [12]. The typical droop control based on P-f and Q-V characteristics improved in Reference [13] avoids the switch of control strategies and achieves the smooth transition when operating modes change. Reference [14] adopts an integrated control strategy that integrates master-slave control with peer-to-peer control to control the operation mode transition between grid-connected operation mode and islanding operation mode of micro-grid. Reference [15] considers decentralization of the distributed generation units and loads in the micro-grid and concentrating on generation types and models of the storage devices, using different control strategies in controller design for the distributed generation units.

When the regular grid breaks down or the power quality cannot meet the requirements, micro-grids will disconnect with regular grids and forms into islanding operation.

(1) Master-Slave control

In the micro-grid system, the master-slave control is that one or several micropower control all of micro-power according to V/f control. Except the main control source, other micro-powers often adopt P-Q control, the constant power control. The main control source which adopts V/f control supplies reference of voltage and frequency to other micro-powers [16]. The process of master-slave control method goes as follows [17]:

1) When islanding is detected, or the grid disconnects from the distribution network into the islanding operation mode, micro-grid control will switches to the master-slave mode, by adjusting the various micro-power output to reach the balance of power.

2) When the micro-grid loads change, firstly the main power adjusts output current automatically according to the load change. At the same time system detects and calculates the power variation to adjust their output power; when other powers' output power increase, the output of the main power will automatically reduce accordingly to ensure that the main power always has enough capacity to adjust the change of instantaneous power.

3) When the grid lacks for active power or reactive power, system can only rely on the main unit to adjust. When the loads increase, according to the load characteristics, system will reduce voltage appropriately.

(2) Peer-to-peer control

Peer-to-peer control is that all of the DGs have equal status in the control in the system of micro-grid. There is no hierarchy among the controllers. Each DG is on the control according to signals at the point where system voltage and frequency access. Only peer-to-peer control can make the micro-grid plug-and-play. In general, in the control strategy DGs are allowed to control by using only local information, namely control does not depend on communication [18].

In peer-to-peer control mode, when the micro-grid runs in islanding mode, each DG used droop control strategy will be involved in the regulation of the voltage and frequency in the micro-grid [19]. In theory, peer-to-peer control can improve the 
reliability of system and reduce the cost, so peer-to-peer control strategy has been widely concerned.

(3) The multi-agent control

At present, multi-agent technology in the application of the micro-grid is focused on the control of frequency, voltage, etc. The multi-agent control of micro-grid is based on the system of traditional grid control. Multi-agent control possesses autonomy, responsiveness and spontaneous behavior. These characters can meet the needs of distributed control of micro-grid and provide a system that can embed with kinds of control without managers [20]. Figure 2 illustrates a single-line diagram of a micro-grid that contains a BESS, a MGT, and a smart load [21].

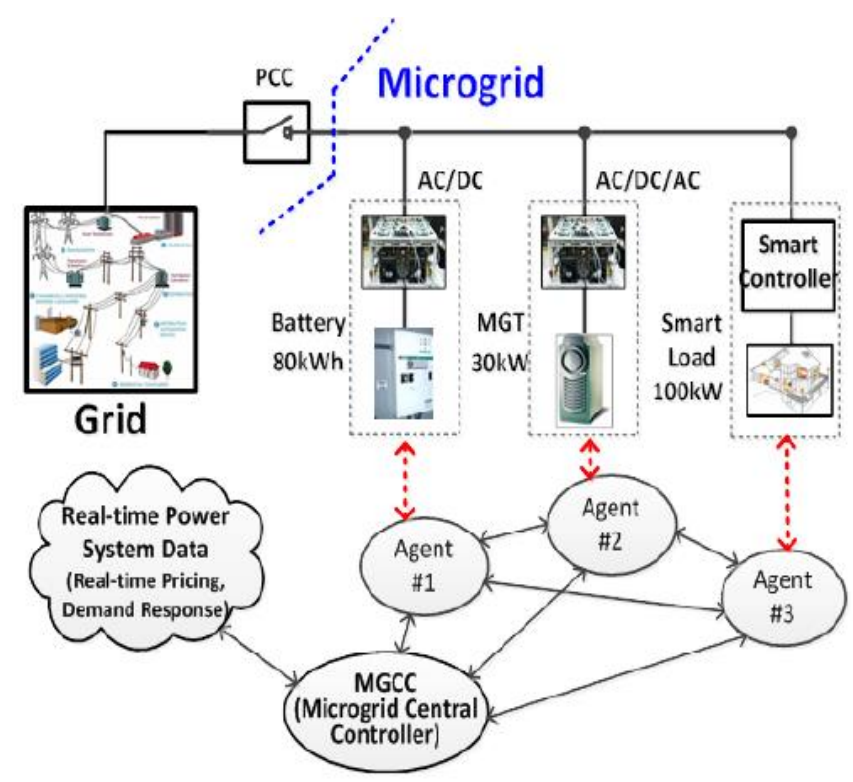

Figure 2. Configuration of Micro-Grid with MAS-Based Control System

\section{Development in Foreign Countries}

Currently, the micro-grid laboratory and the construction of the demonstration project are particularly interested on it. The European Union, together with the United States, Canada, Japan and other countries have built micro-grid projects with their own characteristics, and carried out the related research work [22]. Table 1 is the objective of micro-grid in EU, America and Japan.

Table 1. Objective of EU, America and Japan Micro-Grid [23]

\begin{tabular}{|c|c|c|c|}
\hline Objective & EU & America & Japan \\
\hline Reliability of power supply & & $\sqrt{ }$ & $\sqrt{ }$ \\
\hline $\begin{array}{c}\text { Reduction of environmental impact of } \\
\text { electricity supply }\left(\mathrm{CO}_{2} \text { reduction) }\right.\end{array}$ & $\sqrt{ }$ & $\sqrt{ }$ & \\
\hline $\begin{array}{c}\text { Reduction of investment in plant, equipment } \\
\text { and cost }\end{array}$ & & $\sqrt{ }$ & \\
\hline Increase of energy efficiency & $\sqrt{ }$ & & $\sqrt{ }$ \\
\hline Ensure diversity of energy supply & $\sqrt{ }$ & $\sqrt{ }$ \\
\hline $\begin{array}{c}\text { Power supply to island and/or remote site } \\
\text { Ride-through capability provided by energy } \\
\text { storage }\end{array}$ & $\sqrt{ }$ & $\sqrt{ }$ & \\
\hline
\end{tabular}




\subsection{Micro-Grid Control Research in USA}

The concept of micro-grid is proposed firstly in America, which is the most authoritative in all of concept of micro-grid. In recent years, the research focuses mainly on meeting the requirements of a variety of power quality, improving the reliability of power supply, and reducing the cost and realizing intelligence, etc. [16].

In 2001, the United States enacted the IEEE P1547/D08 'draft of distributed power supply and power system interconnection standards', and passed the relevant law to make the system of the distributed generation system connected on the grid, but also regulated distributed energy: when power system broke down, the distributed power supply must be immediately run out, which greatly limits the distributed energy efficiency from full play [24].

The Mad River is the first demonstration engineering undertaken by power system in North America. The module, simulation method, protection, control strategy and the economic benefit of micro-grid have been proved in the engineering, and the management rules and regulations of micro-grid has been revised [25].

\subsection{Micro-Grid Control Research in Japan}

Micro-grid is still at the demonstration stage at present, but in Japan the microgrid demonstration project construction keeps as a world leader [26].

Mitsubishi in Japan gives us such a definition to micro-grid: a micro-grid is a small-scale controllable system that includes loads, electricity and heat energy equipment. Externally, it is an overall element that can be connected with the main network. Mitsubishi also fills the independent power system charged by traditional power supply into the micro-grid category. Therefore, the definition scope of 'micro-grid' in CERTS is greatly expanded in Japan. Micro-grids can be divided into three types on scale level in Japan, as is shown in Table 2:

Table 2. Classifications of Micro-Grids by Mitsubishi Ltd [27]

\begin{tabular}{|c|c|c|c|c|}
\hline Type & $\begin{array}{c}\text { Generation } \\
\text { Capacity /MW }\end{array}$ & Fuel & Applications & Market Scale \\
\hline Large Scale & 1000 & Oil or coal & Industrial site & $10 \sim 20$ \\
\hline Medium Scale & 100 & $\begin{array}{c}\text { Oil or coal or } \\
\text { renewable } \\
\text { energy sources }\end{array}$ & Industrial zone & 100 \\
\hline Small Scale & 10 & $\begin{array}{c}\text { Renewable } \\
\text { energy sources } \\
\text { power grid, } \\
\text { residential } \\
\text { building, island, } \\
\text { remote area }\end{array}$ & 3000 \\
\hline
\end{tabular}

\subsection{Micro-Grid Control Research in Europe}

Figure 3 presents the schematic diagram of the Bronsbergen Holiday Park microgrid. This is one of the More Micro-grids projects that were supported by the European Union. Bronsbergen Holiday Park consists of 208 holiday homes. The micro-grid is formed in the park and the generation comes from 108 roof fitted solar PVs and the peak generation capacity is $315 \mathrm{~kW}$. The micro-grid is connected to a $10 \mathrm{kV}$ medium voltage grid through a $400 \mathrm{~kW}$ transformer (400 V/10 kV) [28]. 


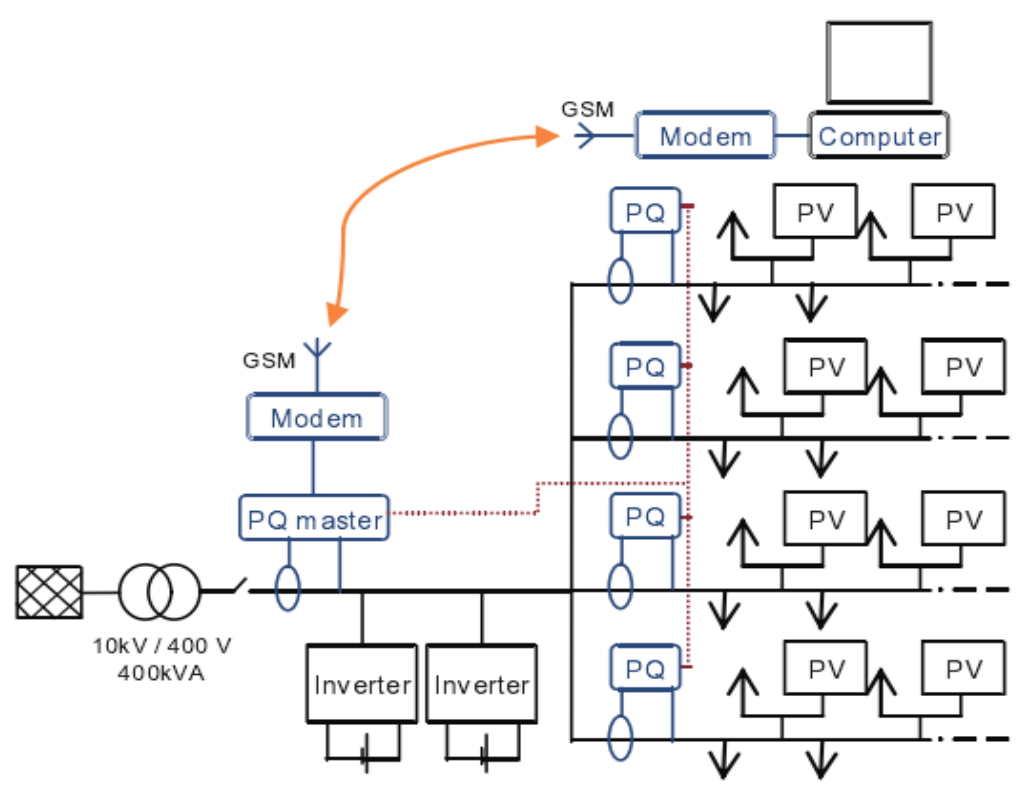

Figure 3. Schematic Diagram of the Bronsbergen Holiday Park Micro-Grid

\section{Domestic Situations}

In 2008, the total greenhouse gas of China emissions came followed in the world. At the top 20 most polluted cities of the world, China took the 16th seats; In addition, one hundred billion RMB lost each year because of the acid rain generated by thermal power emissions [29].

In 2008, the wind power of China has reached $10 \mathrm{GW}$, as is expected to reach $50 \mathrm{GW}$ in 2015. China has become the world's largest photovoltaic cell producer. Photovoltaic power generation is expected to increase at an average rate of $40 \%$ each year in the period of "twelfth five-year", and to reach to 10GW in 2020 [30].

As is shown in Table 3, micro-grids in China can be classified into two types according to the running characteristics [31].From table 3, micro-grids in the remote area mainly supply power to themselves. They need not to connect the grid. Microgrids in city devote to maintain vital power supply, secure reliability and prevent disasters in emergency condition.

Table 3. Characteristics of Micro-Grid in China

\begin{tabular}{|c|c|c|c|}
\hline \multirow{2}{*}{$\begin{array}{c}\text { Type of } \\
\text { Micro-grids }\end{array}$} & Micro-grids district in city & Village micro-grids & $\begin{array}{c}\text { Micro-grids in remote area } \\
\text { grids }\end{array}$ \\
\cline { 3 - 4 } $\begin{array}{c}\text { Operation } \\
\text { Modes }\end{array}$ & GD, IG & \multicolumn{2}{|c|}{ GI, IG } \\
\hline $\begin{array}{c}\text { Distributing } \\
\text { Area }\end{array}$ & Economic developed area & $\begin{array}{c}\text { Village, suburb, prairie, mountain region and } \\
\text { other remote areas }\end{array}$ \\
\hline $\begin{array}{c}\text { Voltage Class } \\
\text { Mid-voltage distribution } \\
\text { network(10 kV) }\end{array}$ & $\begin{array}{c}\text { Low-voltage } \\
\text { distribution network } \\
\text { (400) }\end{array}$ & $\begin{array}{c}\text { Mid-voltage } \\
\text { distribution network } \\
\text { (10 kV or more) }\end{array}$ \\
\hline Capacity & Hundreds Watts to 10MW & $\begin{array}{c}\text { Thousands Watts to } \\
\text { hundreds thousands } \\
\text { Watts }\end{array}$ & $\begin{array}{c}\text { hundreds thousands } \\
\text { Watts to 10MW }\end{array}$ \\
\hline
\end{tabular}




\begin{tabular}{|c|c|c|c|}
\hline $\begin{array}{c}\text { Main } \\
\text { Purposes }\end{array}$ & $\begin{array}{l}\text { Maintain vital power supply, } \\
\text { secure reliability, electricity } \\
\text { quality, energy saving and } \\
\text { discharge decreasing and } \\
\text { capacity to prevent disasters } \\
\text { in emergency condition }\end{array}$ & $\begin{array}{l}\text { Use renewable energy } \\
\text { sources to supply } \\
\text { electricity for remote } \\
\text { areas, and promote } \\
\text { urbanization in villages }\end{array}$ & $\begin{array}{l}\text { Improve electricity } \\
\text { reliability and } \\
\text { efficiency of energy } \\
\text { utilization and lower } \\
\text { the cost }\end{array}$ \\
\hline $\begin{array}{c}\text { Main Types } \\
\text { of Micro- } \\
\text { power }\end{array}$ & $\begin{array}{l}\text { Clean power generation (fuel } \\
\text { cell, micro gas turbine, diesel, } \\
\text { etc.) and renewable energy } \\
\text { generation (solar power } \\
\text { generation, etc.) }\end{array}$ & $\begin{array}{l}\text { Renewable energy } \\
\text { generation (wind power } \\
\text { generation, solar power } \\
\text { generation, biogas } \\
\text { power generation, etc.) }\end{array}$ & $\begin{array}{l}\text { Traditional power } \\
\text { supply type }\end{array}$ \\
\hline \multicolumn{4}{|c|}{$\begin{array}{l}\text { Note: } \\
\text { 1) GD (Grid Dependent Mode): Connects with large grids and exchanges powers; } \\
\text { 2) GI (Grid Independent Mode): Referred also as Independent Operating Mode, connects with } \\
\text { large grids without exchanging powers, internally generate with self-sufficiency; } \\
\text { 3) IG (Isolated Grid Mode): Condition of islanding, operates by itself when disconnected with } \\
\text { large grids. }\end{array}$} \\
\hline
\end{tabular}

Figure 4 is the framework of Zhangbei wind/ solar/ battery demonstration project [32]. The demonstration project adopts the strategy of peer-to-peer to manage power output. The micro-grid system has two kinds of distributed power: wind turbine and photovoltaic. The current that micro-powers generate flows together to the $35 \mathrm{kV}$ AC bus. Then the current supplies to users or charges to batteries through the monitor and control system.

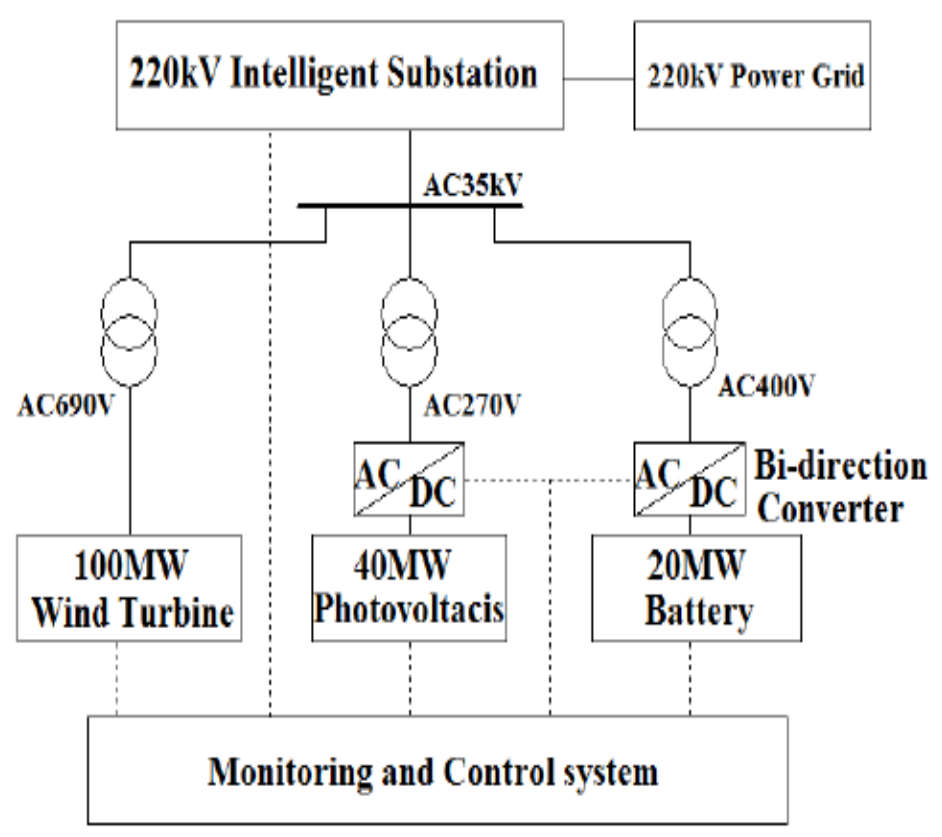

Figure 4. The Framework of Zhangbei Wind/ Solar/ Battery Demonstration Project 
According to the structure and definition above, the control of micro-grid is based on electronic technology, distributed generation and energy storage technology. The micro-grid has the following advantages [33]:

(1) The micro-grid provides an effective way to integrate application of DG, owning all of the advantages that system of single DG has.

(2) As an independent unit module, the micro-grid has no harmful influence on power grid, thus it does not need to modify the operation of the power grid.

(3) DG can be switched in a flexible manner, namely the DG having the ability which is called 'plug-and-play'.

(4) The connection of DG can increase the system capacity, has corresponding system of energy storage to make inertia of system increase, reduces happening for the phenomena of voltage fluctuation and voltage flicker, and improves power quality [34].

(5) In the superior network failure, the micro-grid can supply power continually as an isolate running module, and improve power supply reliability [35].

\section{Conclusion}

Although micro-grids have a good and broad prospect, there are still some issues remaining unsolved.

(1) The cost for achieving the micro-grid control.

In the process of actual operation, the control of the micro-grid has become more accurate and more conform to the requirements of the regular grid. But with the improving of accuracy, the cost of control equipment's increases. It will make the whole distribution network operation uneconomic. Especially when some of medium voltage distribution network has high reliability, the reliability of micro-grid however, is often unable to fill the high cost of the loss of economy [36].

(2) Reliability of the distributed power supply.

Compared with the traditional power, the output power of micro-power is generally small, intermittent and random. Due to the variety of micro-power, the output power is not with the same features [37]. Thus, it is difficult to coordinate all the micro-powers to supply.

(3) The power quality

Although peer-to-peer control strategy is more stable, it is considered only on primary frequency control, without the recovery of system voltage and frequency [38]. Currently, most of the researches are still remaining at the experimental stage, so achieving peer-to-peer control needs some further research [39-42].

(4) The protection based on control of micro-grid

Now, most of researches concentrate on the strategy of micro-grid control, but for the protection, micro-grid is still stagnating at the theoretical stage [43-46]. Reference [47] introduces a centralized protection system for micro-grid, shown as Figure 5. As the traditional protection cannot interrupt the fault accurately, microgrid system needs to build a protection based on control to switch a solar panel or a wind turbine instead of all the DGs. 


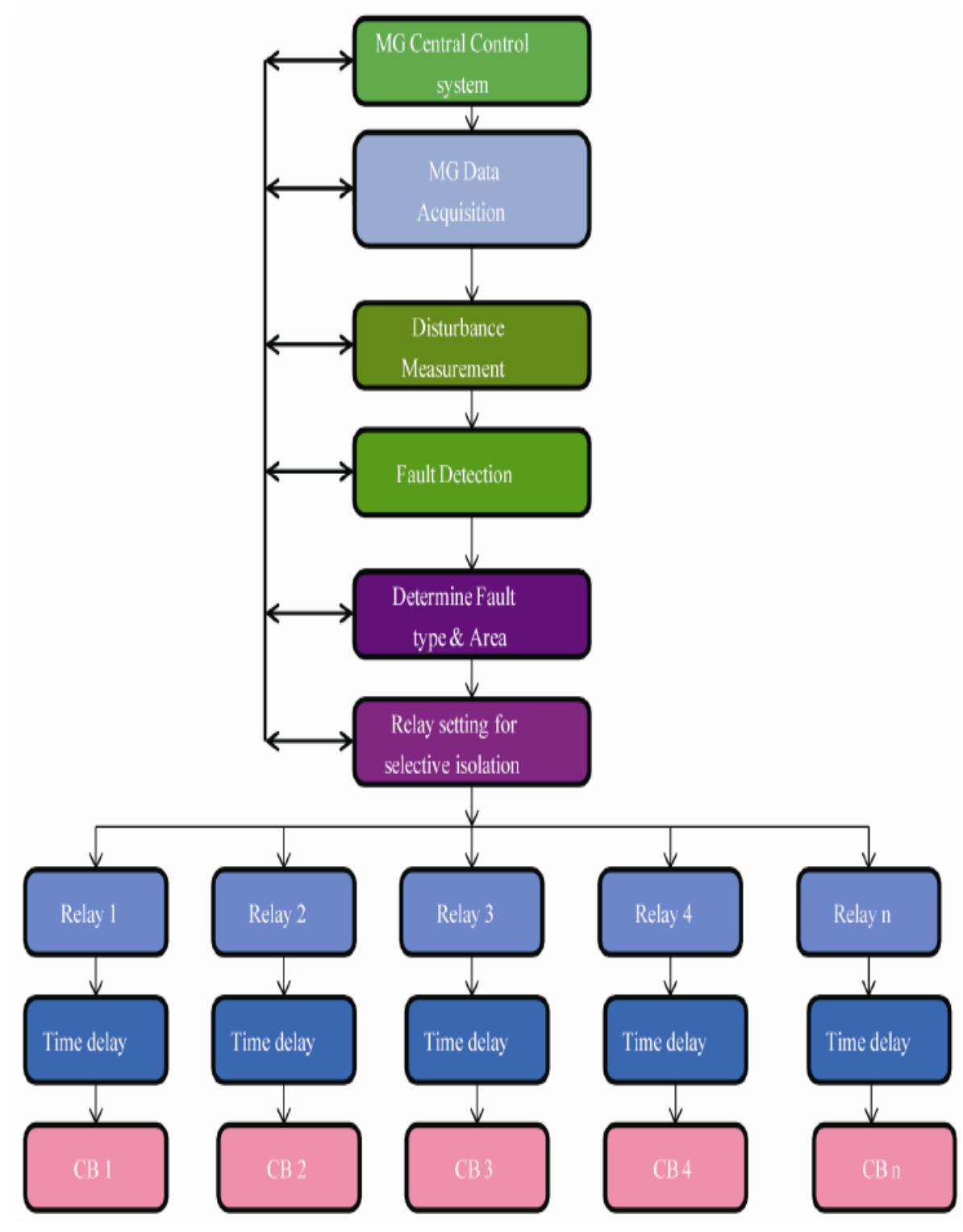

Figure 5. Centralized Protection System for Micro-Grid

As is analyzed above, micro-grid control can solve the problems of energy distribution, mode switching and load control. But there are still some further problems that need researchers to deal with and probe.

\section{Acknowledgements}

This work is supported by National Nature Science Foundation of China under Grant 61304069, 61372195, 61371200 the Nature Science \& Foundation of Liaoning Province under Grant 2013020124, the Key Technologies R\&D Program of Liaoning Province under Grant 2011224006, 2012201010, the Key Project of Chinese Ministry of Education under Grant 212033, the Science and Technology Program of Shenyang under Grant F11264-1-70 and the Scientific Research Fund of Liaoning Provincial Education Department under Grant L2013494, L2012374. 


\section{References}

[1] W. Huang, M. Lu and L. Zhang, Energy Procedia, vol. 12, no. 206, (2011).

[2] Z. X. Lu, C. X. Wang, Y. Min, S. G. Zhou, X. Lv and Y. B. Wang, Automation of Electric Power Systems, vol. 31, no. 100, (2007).

[3] X. G. Kong, Z. Q. Liu and J. H. Zhang, Energy Procedia, vol. 16, no. 1678, (2012).

[4] M. Ding, K. Ma and R. Bi, Power System Protection and Control, vol. 41, no. 1, (2013).

[5] F. Katiraei and M. R. Iravani, IEEE Transactions on Power Systems, vol. 21, no. 1821, (2006).

[6] I. Serban and C. Marinescu, Renewable Energy. 36, 3345 (2011).

[7] X. S. Tang, W. Deng, N. N. Li and Z. P. Qi, Electric Power Automation Equipment, vol. 32, no. 99, (2012).

[8] Y. T. Yang, Y. B. Zhang and G. Q. Weng, Journal of Mechanical and Electrical Engineering, vol. 27, no. 14, (2010).

[9] F. Tang, M J. Guerrero, X. Zhou, T. Y. Ma and J. C. Vasquez, "Automation of Electric Power Systems", vol. 38, no. 15, (2011).

[10] J. H. Zheng, Y. T. Wang and X. W. Li, Automation of Electric Power Systems, vol. 35, no. 17, (2011).

[11] L. Guo and C. S. Wang, Automation of Electric Power Systems, vol. 33, no. 82, (2009)

[12] G. D. Wang, China Electric Power, vol. 5, no. 10, (2012).

[13] C. S. Wang, F. Gao, P. Li, B. W. Huang, C. D. Ding and H. Yu, Proceedings of the CSEE, vol. 32, no. 2, (2012).

[14] D. M. Zhao, N. Zhang, Y. H. Liu and X. Zhang, Power System Technology, vol. 37, no. 301, (2013).

[15] C. S. Wang, Z. X. Xiao and S. X. Wang, Automation of Electric Power Systems, vol. 32, no. 98, (2008).

[16] W. L. Liu, H. D. Zhang and K. L. Dong, Electrotechnics Electric, vol. 2, no. 1, (2012).

[17] S. B. Bai, "The Study on the Control of Micro-grid", Tianjin: Tianjin University, (2008).

[18] Z. Y. Tang, "The Peer-to-peer Control of Microgrids and the Research of the Operating Characteristic", Nanjing University of Science and Technology, (2013).

[19] C. S. Wang, Z. G. Yang, S. X. Wang and Y. B. Che, Automation of Electric Power Systems, vol. 34, no. 99, (2010).

[20] L. Su, J. H. Zhang, L. Wang, W. S. Miao and Z. P. Wu, Power System Protection and Control, vol. 38, no. $235,(\mathbf{2 0 1 0})$

[21] Il-Y. Chung, C. H. Yoo and S. J. Oh. Engineering, vol. 5, no. 1, (2013).

[22] C. S. Wang and P. Li, Automation of Electric Power Systems, vol. 34, no. 10, (2010).

[23] Z. X. Xiao, J. Z. Wu and N. Jenkins, Intelligent Automation \& Soft Computing, vol. 16, no. 199, (2010).

[24] R. H. Yang, W. Huang, L. Guan and L. F. Liu, Power System and Clean Energy, vol. 26, no. 48, (2010).

[25] W. Huang, C. H. Sun, Z. P. Wu and J. H. Zhang, Power System Technology, vol. 33, no. 14, (2009).

[26] C. C. Wang and Q. P. Du, North China Electric Power, vol. 8, no. 56, (2013).

[27] S. H. Xu and J. L. Li, Proceedings of the CSEE, vol. 33, no. 25, (2013).

[28] N. W. A. Lidula and A. D. Rajapakse, Renewable, Sustainable Energy Reviews, vol. 15, no. 186, (2011)

[29] W. L. Zhang, Z. Z. Liu, M. J. Wang and X. S. Yang, Power System Technology, vol. 33, no. 1, (2009).

[30] Y. Yuan, Z. J. Li, Y. Feng and W. X. Zuo, Automation of Electric Power Systems, vol. 34, no. 59, (2010).

[31] S. S. Shi, Z. X. Lu, S. X. Zhou and Y. Min, Electric Power, vol. 42, no. 21, (2009).

[32] X. Wu, X. G. Yin, Q. Wei, Y. F. Jia and J. Wang, Energy and Power Engineering, vol. 5, no. 171, (2013).

[33] H. Guo, J. H. Su and G. R. Zhang, Sichuan Electric Power Technology, vol. 32, no. 1, (2009).

[34] H. Cheng and Z. Xu, High Voltage Apparatus, vol. 39, no. 53, (2003).

[35] F. Li, X. Y. Li and W. Hao, Relay, vol. 35, no. 13, (2007).

[36] Z. J. Ma, H. Z. Cheng, K. Chen, Y. Long and X. X. Gong, Modern Electric Power, vol. 30, no. 7, (2013).

[37] Z. H. Bie, G. F. Li and X. F. Wang, Electric Power Automation Equipment, vol. 31, no. 1, (2011).

[38] P. J. Han, H. J. Zhang, H. B. Li and L. L. Li, Power System and Clean Energy, vol. 28, no. 25, (2012).

[39] C. Marnay, F. J .Rubio and A. S. Siddiqui, Shape of the Microgrid, (2007) January.

[40] R. H. Lasseter, Microgrids. Proceedings of 2002 IEEE Power Engineering Society Winter Meeting, New York, NY. USA. Piscataway, NJ, USA: IEEE, vol. 1, (2002) January 27-31, pp. 305-308.

[41] R. Lasseter, A. Akhil and C. Marnay. Stephens, "Integration of Distributed Energy Resources: the CERTS Microgrid Concept", [EB/OL], (2007) April.

[42] N. J. Gil and J. A. P Lopes, "Hierarchical Frequency Control Scheme for Islanded Multi-microgrids Operation", Processdings of IEEE Lausanne Conference on Power Technology, Lausanne, Switzerland, (2007) July 1-5, pp. 473-478.

[43] N. D. Hatziargyrious, A. Dimeas, A G. Tsikalakis, J. A. Pecas Lopes and G. Kariniotakis, "Management of Microgrids in Market Environment", Processdings of 2005 Intenational Conference on Future Power System, Netherlands, (2005) November 1-7.

[44] A. Dimeas and N. Hatziargyriou, "A Multi-agent System for Microgrids", Proceedings of IEEE Power Engineering Society General Meeting, Denver, USA, (2004) June 6-10, pp. 55-58.

[45] J. P. Barton and D. G. Infield, IEEE Trans on Energy Conversion, vol. 19, no. 441, (2004).

[46] F. Katiraei, M. R. Iravani and P. W. Lehn, IEEE Trans on Power Delivery, vol. 20, no. 248, (2005). 


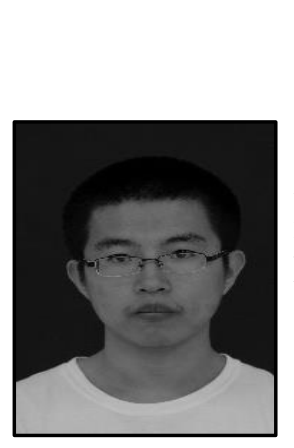

\section{Authors}

Jingwei Hu received the B.E. degree in Electrical Engineering and Automation from Shenyang Institute of Engineering, Liaoning, China in 2013.He is currently working towards the Master in Electrical Engineering in Shenyang Institute of Engineering.

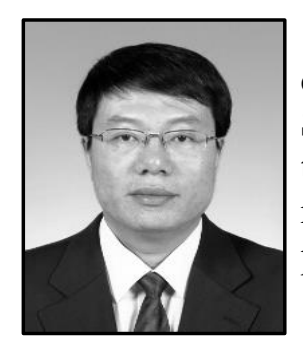

Tieyan Zhang was born in 1962. He received the Ph.D. degree in control theory and control engineering from Northeastern University, Shenyang, China, in 2007. He is currently a professor and president of the Shenyang Institute of Engineering, Shenyang. His current research interests include fuzzy controls, fault diagnosis on electric power systems, and stability analysis on smart grids.

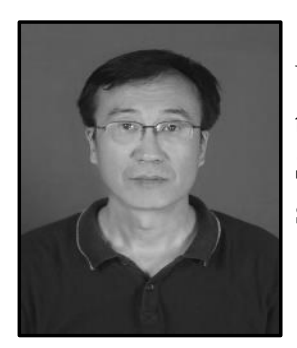

Shipeng Du received the B.E. degree in Northeast Dianli University, Jilin, China. He is currently an associate professor with the School of Renewable Energy, Shenyang Institute of Engineering, Shenyang. His current research interests include micro-grid control, sensor theory.

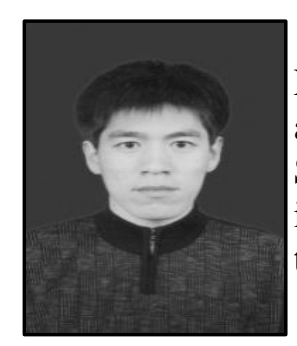

Yan Zhao received the Ph.D. degree in control engineering from Northeastern University, Shenyang, China, in 2008. He is currently an associate professor with the School of Renewable Energy, Shenyang Institute of Engineering, Shenyang. His current research interests include fuzzy control theory and distributed generation technique. 